\title{
Greek Gastarbeiter in Germany and European Expatriates from Greece: Diaspora Interactions between Immigrants and Neo-Immigrants
}

\begin{abstract}
By Eleni D. Tseligka*
Between 1953 and 1973, emigration depleted the Modern Greek state by roughly one fifth of its total population. A significant number of those migrants relocated to Germany, which since 1960, has been home to a sizeable community of former Gastarbeiter (guest-workers) and their descendants. Following three decades of European Integration and relative prosperity, the 2009 Greek sovereign debt crisis initiated a new wave of Greek emigration, analogous, yet different to that of the postwar era. Germany remains an attractive destination for Greek expatriates, but in contrast to guest-workers from the 1960s, "neo-migrants" are typically skilled or highlyskilled persons who relocate individually. This paper examines the qualitative attributes of Greek expatriates and "neo-migrants" in Germany and compares them to those of former guest-workers; furthermore, this paper compares the narratives of Gastarbeiter to those of European expatriates. Finally, the perceptions of Greek expatriates for the established Greek community in Germany are looked into, as well as the individual and collective efforts of the Greek community and institutions to help and ease their socioeconomic integration.
\end{abstract}

Keywords: Gastarbeiter, neo-migrants, expatriates, Germany, Greece

\section{Introduction}

Germany is home to a sizable Greek community, which consists of former guest-workers from the 1960s and their descendants, but also of European expatriates who emigrated to Germany after Greece's induction to the European Communities and subsequently to the European Union. Guest-worker immigration to Germany was the result of bilateral agreements between the state of origin and the host state, which constituted a strict and inflexible migratory regime. On the other hand, European expatriation is a liberal migratory condition based on the freedom of movement, one of Europe's founding principles. Neo-migrants is a term used colloquially by the Greek press to describe post 2010 crisis-driven emigrants to Germany and other destinations, regardless of the fact that they are not excluded from the privilege of European expatriation. However, in this paper the term is used to distinguish crisis-driven emigrants ${ }^{1}$ from the established Greek Diaspora as well as the Greek European expatriates in a temporal manner but also in terms of motives, relocation patterns and integration opportunities. This paper

\footnotetext{
*Professional Development Advisor for Reseach, Aston University, U.K.

${ }^{1}$ The Greek sovereign debt crisis of 2009, which followed the international financial crisis of 2007 and 2008 with the collapse of the Lehman Brothers (Tseligka 2016), resulted in severe austerity measures that brought a dramatic increase of unemployment (Sotiropoulos and Bourikos 2014), as well as the resurgence of Greek emigration.
} 
highlights the differences between the qualitative attributes of Greek expatriates and neo-migrants compared to those of guest-workers, and also looks at the interaction between the established Diaspora and the newcomers, as it is reflected in the narratives of each group, shaped by the historical context and the individual experience.

\section{Data and Methods}

The narratives analysed in this article come from thirty-one semi-structured interviews, with outstanding individuals such as academics and diplomats and leading figures of the Greek communities in Germany, individuals in pastoral and parental roles, such as elected representatives of migrant associations, clerics and educators. All interviewees were selected due to their significant experience on issues of the Greek Diaspora in Germany. In all cases, it was made certain that each of the interviewees combine as many of the attributes of a good informant as possible. For example, one of the clerics interviewed is a first-generation guestworker and founder of an immigrant association, who later in life obtained education, was ordained a priest and became a writer on subjects of the Diaspora, while another is an academic who originally expatriated in Germany as a student.

All interviews were conducted between December 2012 and May 2013 and an indicative sample of fifteen of those interviews is partly featured in this article. Approximately half of the interviewees of this sample are first or secondgeneration migrants, while the other half are European expatriates. The selection of this sample was carefully chosen to equally represent the narratives of both the established Diaspora and the European expatriates, but also highlight the position of Greek institutions in Germany, such as the diplomatic corps and the Church. Particular details regarding each interviewee might constitute a breach of anonymity and cannot be disclosed.

The sum of interviews were conducted as part of a larger qualitative research project that examines the sociopolitical integration of Greeks in Germany before and after the Maastricht Treaty, based on participant observation and semistructured interviews. The research, titled "From Gastarbeiter to European Expatriates" was conducted under the aegis of Staffordshire University and the bulk of its findings were released as a monograph in 2019, under the same title. It remains the only in-depth study of Greek emigration in Germany and offers insights on the process of European Integration from the sociopolitical perspective of intra-European migration before and after the Maastricht Treaty, highlighting the transformation that migratory and diasporic typologies have undergone between 1960 and 2016 (Tseligka 2019).

The total of interviewees was carefully selected from fourteen locations in Germany, in particular Berlin, Bielefeld, Bonn, Cologne, Darmstadt, Dortmund, Düsseldorf, Erfurt, Jena, Munich, Rüsselsheim, Siegen, Stuttgart and Weimar. The selection of places was not random, as locations were chosen for the size of their communities and their importance in the history of Greek migration and establishment in Germany. 


\section{Gastarbeiter (Guest-Workers)}

The end of the Second World War found Greece in ruins, with most of its infrastructure destroyed and more than half a million dead. The four years of Nazi occupation left one quarter of all villages laid to waste and a great proportion of the rural population internally displaced, seeking refuge in the cities, yet failing to integrate, thus remaining unemployed, horribly poor and with little hope of future improvements (Shrader 1999). The general malnutrition of the population, paired with a shortage of medical supplies and inadequate sanitation conditions, resulted in the resurgence of tuberculosis and malaria. Aid provided by the Allies, the United Nations Relief, the Rehabilitation Administration (UNRRA) and overseas Greeks in 1945 was just enough to prevent famine. The needs of the population for food were so dire that despite the 100 million US dollars in food donated during that year, the optimal daily ration of two thousand calories per person was not possible (Shrader 1999). The end of the Second World War however, did not signify the end of bloodshed for Greece, but the beginning of a four-year civil war, which claimed the lives of an additional 158,000 people and caused further destruction of public and private property; the outcome of that war solidified Greece's position in the Western Bloc during the Cold War era (Koliopoulos and Veremis 2009). Between 1947 and 1952 the Bank of Greece came under American supervision, which maintained the stability of the drachma ${ }^{2}$, but led to gold coin hoarding since people did not trust banks with their savings. Despite its downsides, being a member of the Western Bloc and NATO as of 1951, secured much needed funds for Greece that was included in the Truman Doctrine, which established an era of US involvement in European politics (Koliopoulos and Veremis 2009).

Germany's state after the end of the Second World War can only be described as a big pile of rubble. Most major cities, but also many towns and villages, had been heavily bombed during the final stages of the war and most of the country's infrastructure was reduced to ash and debris. Significant cultural monuments, some dating back to the Roman Empire, were pulverised and had to be bulldozed away with the rest of the rubble. The general situation was so bad that the American Headquarters had to be placed in the spa town of Wiesbaden, which had been spared from bombing due to bad weather. The civilian death toll was dreadful, and fear of the Red Army pushed the survivors of the eastern provinces to the west, in the hope that the Western Allies would be more merciful than the Soviets (MacDonogh 2009). The first government of West Germany was formed in 1949 by Konrad Adenauer and introduced the country's economy to the free price mechanism, leading to price reductions and increase of productivity (Van Hook 2004). During the 1950s, while Greece's economy was almost entirely dependent on loans and foreign aid, the economic growth rates of Germany became so impressive that it was considered an economic miracle, or as the Germans called it, Wirtschaftswunder (Braun 1990).

\footnotetext{
${ }^{2}$ The modern drachma was first released in circulation in 1832 (Koliopoulos and Veremis 2009) and remained Greece's national currency until it was replaced by the Euro in 2002.
} 
By the 1960s Germany was already regarded as one of the world's rich counties, yet growth slowed down mainly because of a drop in the flexibility of the labour supply. Since 1949 Germany stood divided in two separate states. The regime in East Germany had made emigration to the West a very dangerous affair, so the flow of workers from East Germany to West Germany had dramatically decreased, and in August 1961, with the building of the Berlin Wall, it stopped altogether. In order to solve the problem of a growing labour deficiency the West German government signed bilateral agreements which allowed foreign individuals to enter the labour force of Germany. A new term was created in the German language to describe the newly arrived workers from the South, Gastarbeiter, guest-workers (Braun 1990). The term described the legal status of immigrants, with few rights and a temporary position in the German society (Tseligka 2019).

Greece was among the first counties to sign such an agreement, on the $30^{\text {th }}$ of March 1960, following Italy and Spain (Meyers 2004). During the 1960s technological breakthroughs in ballistic missiles had significantly lessened the geostrategic importance of Greece. The improved military defence of the state also hindered the possibility of an invasion from its communist Balkan neighbours. That new order of things decreased Greece's importance to the USA and with it the financial aid the country was receiving from its North Atlantic partners (Koliopoulos and Veremis 2009). It was during that time when Greece became interested in the prospect of European integration, which led to its accession to the Council of Europe.

The 1960 bilateral agreement with Germany was advertised as a solution to individual poverty, encouraging people to migrate. The sudden industrialisation of the economy, followed by the urbanisation of the population, both of which began right after the War, resulted in unprecedented unemployment. It is however difficult to put the problem in numbers, as statistics from that era are generally considered unreliable (Charalambis et al. 2004), due to methodological fallacies and the systematic efforts of the Greek government to conceal the poor state of the Greek economy. After the agreement was signed, Germany created a very efficient system to link employers to foreign employees. First, the employers had to apply to their local employment office, declaring how many workers were needed and the skills those individuals should have. Then the employment office would search for workers that were already registered with them in the country, and if they could not find any, they would contact German officials in one of the countries which had agreed to dispatch workers. Until 1973 the recruitment of foreign workers bore no restrictions, except for the 1967-1968 period, marked by a recession during which the German government refused to extend work permits (Meyers 2004).

The German Committee in Greece maintained two recruitment offices, the first in Athens, at Viktoros Ougko Street, near Omonoia Square, and the second in Thessaloniki at Dodekanisou Street (Rimpa 2010). The guest-workers played an important role in the development of the German economy from the 1960s onwards. Their presence created an economic order and policy which was growth oriented and some of them introduced new, improved skills and work ethics into the job market. Of course, the immigrants were not the only factor which took the 
"German miracle" to the next level (Braun 1990). Technological advances and scientific innovations like nuclear power, or the transistor and later on the microchip, which brought forth a new generation of computers, along with the participation of the German state in the Organization for European Economic Cooperation and the European Payments Union, allowed the country to create a highly competitive economy, rebuild itself and leave its Second World War past behind (Braun 1990). The Europeanisation of Germany was seen as a crucial element in the reconstruction of the German state after the disaster of the Second World War. Thomas Mann's dictum of a preferred European Germany instead of a German Europe was taken literally by Chancellor Konrad Adenauer, who since the 1950s initiated the multilateralization of German politics as the best means to overcome Germany's past and solidify its position in the West (Marcussen et al. 2001).

Despite their initial expectations, Greek guest-workers and their families encountered very harsh socioeconomic conditions. The themes of extreme poverty and social exclusion were frequent in the interviews conducted with members of the established Diaspora and often manifested as poor housing conditions for the workers and their families, as attested in the interview segment below, by a second-generation Greek from Cologne.

"I was born in 1966 [...] in the beginning my family's living conditions were difficult. Imagine that during the first year of my life we lived in a modified garage [...] we were raised under difficult circumstances" (T.V. Journalist 2012).

In the 1970s German society was already concerned about the social consequences of foreign labour recruitment, as it became apparent that those who they regarded as guest-workers were in fact immigrants, and in their majority they were not interested in repatriation (Chin et al. 2009). Foreign labour recruitment was banned in November 1973, but most of the immigrants did not go back to their country of origin, mostly out of fear that they would not be able to return to Germany if the situation in the home country was not what they expected (Meyers 2004).

A family reunification law and new policies that would assist integration and eliminate social discrimination were introduced in the 1970s by the German government. A new curriculum was introduced to schools, along with ethnically mixed classrooms, to encourage integration and help create a new paradigm regarding the place of guest-workers in the German society, by exposing Germans to a heterogeneous social model on the one hand, and on the other hand teach foreigners German (Chin et al. 2009).

\section{European Expatriates}

The living conditions of those Greeks who decided to stay in Germany would soon begin to improve, as on the $1^{\text {st }}$ of January 1981, Greece became a full member of the European Communities, including the European Economic Community, the predecessor of the 1993 configuration of the European Union. The changes brought forth by that agreement would progressively bring into legislation the free 
movement of goods and the free movement of persons, services and capital, but also the common customs tariffs between Member States. Further on, that agreement introduced Greece to free movement of workers by the 1st of January 1988, the liberalisation of direct investments from $31^{\text {st }}$ of December 1985, and from the 1st of January 1981 the unblocking of funds and the increase of tourist allowance to no less than 400 European Units (European Union Publications Office 1979). Most importantly, it solidified Greece's position in the European family, shedding new, positive light onto the community. Entrepreneurship was greatly helped by the liberalisation of investments in 1985, but even before that the 1981 unblocking of funds, gave the opportunity to Greek nationals to transfer money they previously kept in Greek banks and invest them into the German economy. Quite often those funds were remittances previously sent home, due to feelings of uncertainty brought forth by German immigration laws (Tseligka 2019). I.P. in Dïsseldorf, a senior cleric of the Greek Orthodox Church, mentioned that "those who wanted to break free from work in the factories were helped (by the EC legislations), as they made use of the new conditions in creating their own businesses" (I.P. Cleric 2013). The above development also promoted social mobility, as people gave up their old jobs in factories to start their own businesses. As explained by Dr T.F., a second-generation Greek academic from Berlin, that increased social mobility, cleared the air from the negative stereotypes of the past, such as that of the poor Greek Gastarbeiter who is a manual labourer, allowing the Greek community to be seen under new light by the German public, even enhancing the concept of European Identity (Dr T.F. Academic 2013).

Greece's accession to the European Communities and later to the European Union, helped the integration and establishment of the Greek Diaspora in Germany. A first-generation migrant and trade unionist from Munich told us in an interview:

"The European Union gave us a voice, it helped us gain political rights since we could vote in the local elections. That was as important as the free movement of people and it helped tremendously in the establishment of Greeks in Germany" (M. F1. Unionist 2013).

Often quoted as an "invisible minority" (in contrast to the concept of a "visible minority", associated with racial minorities) by German authorities, Greeks had reached the highest level of integration in German society, to the point that their presence was considered an essential element of contemporary Germany (Tseligka 2019). At the same time, the ease of relocation within the European Union became one of the pull factors for a new wave of Greek emigration.

"The European Union was tremendous help! The common European passport, or that fact that you don't even need a passport anymore, or a visa, and you can move freely and just like that! Makes you feel so at ease... I was never stopped by the authorities; I was never asked any questions at customs. In all my encounters with the German state I was treated the same way as German citizens and that sense of equality is very important to me. [...] I compare my experience to that of third country nationals and I can clearly see the benefits of the EU. How can one seek his fortune in Germany when $\mathrm{s} / \mathrm{he}$ is prohibited to cross its borders? I have met several third country nationals and I can see for myself their hardships [...]" (G.F15. Teacher 2013). 
The ease of resettlement and the equal treatment changed the qualitative aspects of Greek migration to Germany. The Gastarbeiter of the 1960s and 1970s were by default unskilled or low skilled workers in dire need for work; they fled extreme poverty and, in some cases, political persecution. The European expatriates however left for Germany from a significantly wealthier Greece, to some extent due to the political and financial benefits of Greece being a Member State.

"It is not extreme poverty any longer that brings people here; Greeks do not migrate anymore for the same reasons they emigrated in the 1900s or in the 1960s. The living standards in Greece have since then improved dramatically. The European Union reduced the distance between the two states; bureaucracy it was decreased, and moving from Greece to Germany was never easier. Human mobility has been facilitated by the Union, but the target group of such policies is not the poor, but rather the educated" (Dr T.K. Teacher 2013).

A generation of European citizens has been raised to take mobility for granted, often experienced life abroad at a young age by joining a European program, such as Erasmus, designed especially to promote intra-European mobility of students and scientists. It is quite common for Greek European expatriates to have had their first migratory experience as students.

"I first came to Germany for six months after joining the Erasmus program and I liked it so much that I decided to study the German language, as a foreign language. After I graduated in 1994 I moved to Germany for postgraduate studies. I met my (German) wife and I stayed here. But I think that I truly wanted to stay here (in Germany), at some point I realised that I never really intended to go back to Greece" (N.TH1. Teacher 2013).

Unlike guest-workers, who in most cases did not speak German, successful neo-migrants possess high language proficiency.

"I was a student the first time I came to Germany and was for a month at the University of Frankfurt, to enhance my knowledge of the German language. Then in 2006, after I graduated from the university in Greece, I enrolled in a postgraduate course at the University of Bielefeld. I was really interested in the experience of living abroad and I thought it would really improve my German language skills [...]. I currently work at the school, but I have not decided yet if I will settle here (in Germany) permanently" (A.E. Teacher 2013).

In addition to language proficiency, many of the neo-migrants are highly educated, often through the receiving state's educational system.

"What originally brought me to Germany was the opportunity to study for a funded doctoral title $(\mathrm{PhD})[\ldots]$ I applied to several universities across Europe, but what attracted me to the one I eventually enrolled in, was that they offered me a serious scholarship in order to conduct my research with them [...]. I really had no reason to decline that offer, it was an honour to be selected, it would enhance my CV and it gave me the opportunity for publications" (Dr D.F. Academic 2013). 
That new educated, middle-class face of Greek emigration to Germany disconnected further the image of Greeks from unskilled guest-workers and additionally contributed to their acceptance and integration in Germany (Tseligka 2019). However, the social status of middle-class neo-migrants contrasts with the working-class background of former guest-workers and their descendants, perceiving them as too traditional and insular.

"They keep themselves to themselves; they are a small, micro-archaic, society [...] Their celebrations are so traditional, wherever they gather it looks like a village square [...] and they all smoke indoors[...]" (G.F1. Teacher 2013).

"They are a closed society, their Greekness comes from the 60s and the 70s, I presume it has to do with their rural background $[. .$.$] The huge social changes that took place in$ Greece in the 1980s and onwards have not affected them [...] you can see that even from the way they dress [...] their parties resemble those that can be found in villages..." (N.TH1 Teacher 2013).

\section{Neo-Migrants}

The living conditions in Greece have worsened since the beginning of the economic crisis, particularly due to the rise of unemployment, which reached 27 percent by the end of 2013, as well as the loss of income to salary cuts and the high cost of living (Sotiropoulos and Bourikos 2014). Those circumstances diversified the demographics of neo-migrants in Germany. A.G. is a member of the established Diaspora, born and raised in Germany by Gastarbeiter parents, and actively participates in the charities that provide for neo-migrants.

"Some Greeks think that Germany is the land of opportunity and I think this is wrong. A lot of them (the neo-migrants) go back because they could not find a job. Somebody told them that they can come to Germany to serve at a restaurant or wash dishes and that is mostly the kind of neo-migrants we meet in Dortmund. [...] The majority of neo-migrants who bring their children to our school are without work. Last year several people came, spent the whole year here and in the end they returned to Greece; they did not succeed (to get a job). In Diakonie we organise fundraisings for such cases; us Greeks have now gone to the opposite end (of where they used to be)" (A.G. Teacher 2013).

The lack of secular and organised support system for neo-migrants was highlighted in many of the interviews. "Newcomers first turn to the Church and then perhaps to the Greek community" (Dr T.K. Teacher 2013). Some parishes have set up an informal support system, which introduces neo-migrants to the institutions of the receiving state.

"Yes, they keep coming. We have put together a team, which helps neo-migrants to integrate. We escort them to the German authorities, help them register. We also help them to rent accommodation, and we cooperate with Greek businesses to help them find their first job, if they speak German, or to send them to language school to learn 
German. I prefer to advise them to learn German, so they can integrate better and stand on their own feet instead of depending on the good will of their fellow Greeks" (Dr P.M. Cleric 2013).

However other parishes are overwhelmed by the influx of neo-migrants and acknowledge that they are no longer in a position to help. I.P. is among the few remaining elderly clerics who witnessed Gastarbeiter migration in Germany.

"Unfortunately this period the neo-migrants are one of our biggest problems. First of all, too many are coming; secondly, they do not possess a craft or speak German; and thirdly they are victims of fraudsters from Greece. There are so called agencies that charge between 400 and 800 Euros to find employment for people in Germany [...]. When they arrived at the airport someone from a restaurant was there to pick them up and put them somewhere to sleep [...] a week later they were told that the restaurant does not have a lot of work and it will probably go out of business, therefore they must leave $[\ldots]$ which resulted in those people being made homeless overnight [...]" (I.P. Cleric 2013).

Under the circumstances neo-migrants who had not previously secured work become vulnerable to exploitation and extreme poverty.

"It is not just in Düsseldorf that you see homeless Greeks. A friend of mine was telling me about the same problem in Offenbach-am-Main. They drove to Germany with their cars, Greek licence plates and everything, and now they sleep under the bridges of Main" (G.F12 Teacher).

"Some people believe that they will come to Germany and they will find a job right away; however, that is not the case [...]. Others found themselves victims of exploitation by their fellow Greeks, by those established here. I am not referring to scientists, but those destitute people who are being exploited by their fellow-Greek employers [...]" (Dr T.K. Teacher 2013).

Greece's diplomatic corps in Germany is also overwhelmed by the influx of neo-migrants and turns to the German authorities and the Greek communities for help.

"Back then (in the 1960s) there was a state-orchestrated migratory movement, while present migration is not structured and many of those who attempt to migrate nowadays might not speak the language or have anywhere in particular to go, and often come to the Greek diplomatic authorities in search for shelter. [...] the German institutes as well as the Greek communities provide information through brochures regarding work and accommodation in Germany. The German embassy in Athens offers useful information online as well as hosts relevant events, but also in Germany a system for the reception of Greek migrants has been developed" (A.K. Diplomat 2012).

The system in place, mentioned in the interview segment above refers to the cooperation between the Greek communities and the German institutes, with little if any support from the Greek authorities. 
It is not easy to have a full picture of the new Greek migration to Germany. Greece does not keep records of expatriates, except from those who have transferred their tax base abroad, who are a small minority. Therefore, it relies exclusively on statistical records of the German state and Eurostat. However, European expats need a fixed address in order to register with the German authorities, and that means that homeless Greeks or those residing in temporary accommodation are not being recorded.

"For the past two and a half years, from the beginning of the fiscal crisis in Greece, the migratory flow from our country to Germany has been increased. Particularly, and according to the official statistics being handed to us on a yearly basis from the Federal Statistical Office of Germany (Statistisches Bundesamt, shortly called Destatis), we observe an increase of 78 percent during the first half of 2012 in comparison with the first half of 2011. Equally when comparing the first half of 2011 to that of 2010 we also see an increase of approximately 80 percent. Therefore it is beyond obvious that a very large group of our fellow countrymen from Greece have willingly chosen Germany as their destination towards a better future" (A.K. Diplomat 2012).

"Based on the records given to us by the German authorities, we estimate that since the beginning of the crisis and until now (February 2013) there have been 30,000 new Greek migrants in Germany [...]. We have seen families enrolling their children in Greek schools and after a few months they leave. We are not sure however if they relocate internally in Germany, go back to Greece or go elsewhere in Europe. We also do not know if the parents remain and just send their children back to Greece, to their grandparents, as was done in the 1960s" (Anonymous Diplomat 2013).

In addition to the lack of data from Greek authorities, the free movement of people within the EU allows irregular patterns of return migration, which often complicates data gathering. Short term holidays and family visits for particular reasons, such as a marriage or an emergency, should be considered as an occasional return. A periodic return presents a typology of regular movements, such as visiting for the same holidays each year and staying approximately for the same fixed period of time during every visit. Seasonal returns are usually common for migrants who work for seasonal industries, such as tourism or agriculture, but also teachers and academics. A temporary return entails the will for re-emigration and is motivated by change of circumstances, such as the end of a work contract (King 1978).

The case of Greek migrant workers in Germany offers examples of all the above types of returnees. It is, for example, quite common for people working in education to spend their winter, spring and summer breaks in Greece, demonstrating a typology of periodic return.

"I go to Greece every summer; I spend all of my summers in Greece, Easter too. I don't always visit during Christmas though, I went last year but I don't plan to spend Christmas in Greece this year" (G.F15. Teacher 2013). 
"It has become so easy; it's not expensive any more. Did you know that you can fly with less than twenty Euros if you book early with Ryanair? [...] I visit whenever I'm off work" (N.TH1 Teacher 2013).

"It's my first year in Germany, I've been here since September [...]. I went (to Greece) for Christmas and I've already booked (tickets) for Easter [...]. I'm looking forward to it" (M.F1. Teacher 2013).

Equally, it is common for retired industrial workers to spend six months of the year in Germany, usually during autumn and winter, and return for the remaining six months in Greece.

"My father first came with a five-year contract. He did not speak the language at all, so he was among those who were stuck in the factories [...]. (After his retirement) he returned to Greece, but he could not stay there permanently [...]. He continues to be a permanent resident of Germany [...], he spends six months of the year in Greece and then he comes back (to Germany)" (A.G. Teacher 2013).

"The first-generation ones, you won't find them here (in Germany) at this time of the year (spring); those who are still holding up, have left for Greece already [...]. I call them the "six-month-ers" because they spend six months in each of the two countries" (I.P. Cleric 2013).

\section{Conclusions}

Greece has a long history of dependence on foreign aid and loans, even for financing its most rudimentary requirements for food and medicine. Acting like a protectorate state, it had to surrender part of its sovereignty to whichever state or bloc of states would fund its needs and safeguard its existence. The economic disparity between Greece and Germany in the 1960s led to a bilateral agreement that allowed Greek workers to find employment in Germany, which resulted to the establishment of a Greek Diaspora in the country. Greece's accession to the European Communities and later in the European Union provided the necessary resources for Greece's development and at the same time guaranteed the free movement of people. European expatriation emerged as a new paradigm of migration and changed the qualitative attributes of Greek migrants in Germany. In contrast to guest-workers from the 1960s, European expatriates were mostly middle class and educated individuals.

Roughly fifty years since the bilateral agreement for Gastarbeiter employment was signed, Greece and Germany are once again at the opposite sides of the economic spectrum. Soaring unemployment, a result of Greece's sovereign debt crisis, has made emigration once again attractive to the general population, including low skilled workers without language proficiency. The migratory regime of European expatriation has made relocation between European Member States easy for individuals, but the changed socioeconomic environment has become inhospitable and perilous for low skilled workers. In the absence of state institutions to support the neo-migrants, the established Diaspora is gathering its 
Vol. 9, No. $1 \quad$ Tseligka: Greek Gastarbeiter in Germany and European Expatriates...

own resources to facilitate the integration of newcomers. The Greek-Orthodox Metropolis, along with Greek migrant associations and Christian charities of the Evangelical Church, provide a safety net from impoverishment and homelessness.

\section{References}

Braun H-J (1990) German economy in the twentieth century. London: Routledge.

Charalambis D, Maratou-Alipranti L, Hadjiyanni A (2004) Recent social trends in Greece, 1960-2000. Montreal: McGill-Queen's University Press.

Chin R, Fehrenbach H, Eley G (2009) After the Nazi racial state: difference and democracy in Germany and Europe. Ann Arbor: University of Michigan Press.

European Union Publications Office (1979) Documents concerning the accession of the Hellenic Republic to the European communities. Official Journal of the European Communities 22(11): L 291.

King R (1978) Return migration: a neglected aspect of population geography. The Royal Geographical Society 10(3): 175-182.

Koliopoulos JS, Veremis TM (2009) Modern Greece: a history since 1821. Hoboken: Wiley-Blackwell.

MacDonogh G (2009) After the Reich: the brutal history of the allied occupation. New York: Basic Books.

Marcussen M, Risse T, Engelmann-Martin D, Knopf HJ, Roscher K (2001) Constructing Europe? The evolution of nation-state identities. In T Christiansen, J Knud, E Wiener Antje (eds.), Social Construction of Europe, 101-120. London: SAGE Publications Ltd.

Meyers E (2004) International immigration policy: theoretical and comparative analysis. Gordonsville: Palgrave Macmillan.

Rimpa D (2010) Gastarbeiter or else guest-worker, a part. Elliniki Diaspora 121(Jul-Aug): $3-5$.

Shrader CR (1999) Withered vine: logistics \& the communist insurgency in Greece, 19451949. Westport: Greenwood Press.

Sotiropoulos DA, Bourikos D (2014) Economic crisis, social solidarity and the voluntary sector in Greece. Journal of Power, Politics \& Governance 2(2): 33-53.

Tseligka E (2016) Becoming the other - stereotyping of Greeks by the German press. Continuum 30(6): 627-635.

Tseligka E (2019) From "Gastarbeiter" to European expatriates. Bern, CH: Peter Lang.

Van Hook JC (2004) Rebuilding Germany: the creation of the social market economy, 1945-1957. West Nyack: Cambridge University Press.

\section{Interviews Conducted by the Author}

A.E. Teacher (2013) Interview with L.L. Teacher on $24^{\text {th }}$ April 2013. Bielefeld. [Recording in possession of author]

A.G. Teacher (2013) Interview with A.G. on $22^{\text {nd }}$ April 2013. Dortmund. [Recording in possession of author]

A.K. Diplomat (2012) Interview with A.K. on $20^{\text {th }}$ December 2012. Berlin. [Recording in possession of author]

Anonymous Diplomat (2013) Interview with Anonymous Diplomat on $21^{\text {st }}$ February 2013. Stuttgart. [Notes in possession of author] 
Dr D.F. Academic (2013) Interview with Dr D.F. Academic on $1^{\text {st }}$ May 2013. Erfurt. [Recording in possession of author]

Dr P.M. Cleric (2013) Interview with Archimandrite Dr P.M. Cleric on 22 ${ }^{\text {nd }}$ April 2013. Dortmund. [Recording in possession of author]

Dr T.F. Academic (2013) Interview with Dr T.F. Academic on $28^{\text {th }}$ January 2013. Berlin. [Recording in possession of author]

Dr T.K. Teacher 2013 Interview with Dr T.K. Teacher on 29 ${ }^{\text {th }}$ April 2013. Munich. [Recording in possession of author]

G. F1. Teacher (2013) Interview with G.F1. Teacher on 24 $4^{\text {th }}$ April 2013. Bielefeld. [Recording in possession of author]

G.F12. Teacher (2013) Interview with G.F12. Teacher on $22^{\text {nd }}$ April 2013. Dortmund. [Recording in possession of author]

G.F15. Teacher (2013) Interview with G.F15. Teacher on 22 ${ }^{\text {nd }}$ April 2013. Dortmund. [Recording in possession of author]

I.P. Cleric (2013) Interview with Father I.P. Cleric on $16^{\text {th }}$ April 2013. Düsseldorf. [Recording in possession of author]

M.F1. Teacher (2013) Interview with M.F1. Teacher on $29^{\text {th }}$ April 2013. Munich. [Recording in possession of author]

N. TH1. Teacher (2013) Interview with N.TH1. Teacher on $24^{\text {th }}$ April 2013. Bielefeld. [Recording in possession of author]

T.V. Journalist (2012) Interview with T.V. Journalist on $15^{\text {th }}$ December 2012. Cologne. [Recording in possession of author] 
